\title{
THE DIVERSITY OF STONY CORAL AND THE TENDENCY TO BLEACH BASED ON LIFEFORM IN THE TENGAH PATCH-REEF OF KARIMUNJAWA ISLANDS
}

\author{
Aradea Bujana Kusuma ${ }^{1}$, Erwin Riyanto Ardli², Romanus Edy Prabowo² \\ ${ }^{1}$ Marine Science Department, Universitas Bengkulu \\ ${ }^{2}$ Faculty of Biology, Universitas Jenderal Soedirman, Jalan dr. Suparno 63 Purwokerto 53122
}

\section{A B S T R A C T}

Coral reefs, the habitat of tens of thousands of marine species, are an ecosystem with the highest biodiversity. Several threats, however, have impaired coral reefs. One having a potentially catastrophic effect is the increasing temperature of the ocean that leads to a coral bleaching event. This study aimed to determine the diversity of stony coral based on their lifeform, to assess the condition of reefs by measuring percent cover of live coral, and to determine the bleaching occurrence based on the stony coral lifeform in the Tengah patchreef of Karimunjawa National (Marine) Park. The research was a visual survey with line intercept transects (LIT) used to collect data. The data were presented as percent cover of living coral and their lifeforms. The result showed the diversity of coral in the Tengah patch-reef was very high as indicated by the presence of all coral lifeforms in the study site. The most diverse lifeform was found at $10 \mathrm{~m}$ depth with 13 lifeforms, while the lowest lifeform was found at $3 \mathrm{~m}$ depth with ten lifeforms. The most extensive live coral cover was found at $3 \mathrm{~m}$ depth estimated around $73.71 \%$, and the the lowest coverage was found at $10 \mathrm{~m}$ depth, no more than $50.42 \%$. The bleaching event was found in Acropora branching and Acropora digitate at the $3 \mathrm{~m}$ depth.

Key Words: Karimunjawa, coral reef, lifeform, bleaching

Corresponding author: ARADEA BUJANA KUSUMA | email: aradea.bujana@gmail.com

Submitted: 12-05-2017 | Accepted: 06-02-2018

\section{N T ROD UCT IO N}

The coral reef is a typical tropical coastal ecosystem with net primary production reaching 2,500-11,680 gCm $^{-2}$ year-1 from $^{-1962}$ to 1977 (Gordon \& Kelly, 1962; Stoddart, 1969; Kohn \& Helfrich, 1957; Nair \& Pillai, 1972; Lewis, 1977). Light intensity, salinity, and temperature are environmental factors influence stony coral growth rate. The minimum light intensity for coral growth is $450 \mu \mathrm{mol}$ photons $\mathrm{m}^{-2} \mathrm{~s}^{-1}$ (Guan et al., 2015). The coral endosymbiont living in coral tissue requires light to continuously supply nutrients for its host (Muscatine \& Cernichiari, 1969). Salinity is another limiting factor for hermatypic coral, which can withstand only in water salinity of 28.7-40.4 psu (Guan et al., 2015). Coral can grow optimally in water temperature of $30-31^{\circ} \mathrm{C}$ (Helfinalis, 1998; Ramli, 2003) but tolerate water temperature of $21.7-29.6^{\circ} \mathrm{C}$ (Guan et al., 2015). Coral exposure to water temperature rise by $0.74^{\circ} \mathrm{C}$ is reported to cause bleaching.

The bleaching event is the loss of the symbiotic algae or its pigment as a response of tropical stony coral, Cnidaria, and some mollusks to various environmental stresses (Westmacott et al., 2000; Fitt et al., 2001). Bleaching is commonly caused by anomalies of sea surface temperature rise that exceeds the temperature tolerance of coral and its endosymbionts, the dinoflagellates Symbiodinium known as zooxanthellae (Hoogenboom et al., 2012). In some corals, bleaching can stop tissue growth, skeleton formation, and inhibit sexual reproduction. The coral can survive if the exposure to temperature rise is brief, but lethal if the susceptibility is prolonged (Rani, 2001). Each coral lifeform has a different response to temperature rise. Acropora is reported to bleach more severely relative to other lifeforms (Rani, 2001; Baird et al., 2009, Schoepf et al., 2015; Guest et al., 2016). The coral bleaching response depends on the sensitivity level of zooxanthellae to withstand the temperature rise.

Studies on the coral condition in Karimunjawa Islands have been done by several scholars such as Edinger et al. (1998), Suryanti et al. (2011), Joseph (2013), Biondi et al. (2014), Ekayogiharso et al. (2014), Sulisyati et al. (2014), Andaris et al. (2015), Larosa et al. (2015), and Januardi et al. (2016). Razak (1998) reported that the coral bleaching on the western shore of Menyawakan Island was up to $19.5 \%$ in stony coral. Manuputty \& Budiyanto (2000) reported the coral bleaching event in Karimunjawa covered $20.37-21.03 \%$ of the reef at $3 \mathrm{~m}$ depth. The massive bleaching event occurred in 1998 has significantly reduced the coral health of Karimunjawa reefs (Burke et al., 2002). The Indonesian Reef Check Network technical report summarized the Indonesian coral condition and three mild bleaching events occurred from 1998-2006, including the occurrence in Karimunjawa in December 2006 (Habibi et al., 2008).

However, research on the bleaching response trend based on coral lifeform in Tengah patch-reef of Karimunjawa Islands has never been reported. This study aimed to determine the stony coral diversity based on their lifeform, to assess the condition of the reef by measuring percent cover of live coral, and to determine the bleaching occurrence based on the stony coral lifeform in the Tengah patch-reef of Karimunjawa National (Marine) Park. The results were expected to be used as a reference to predict the first lifeforms to suffer bleaching in the event of environmental changes. 


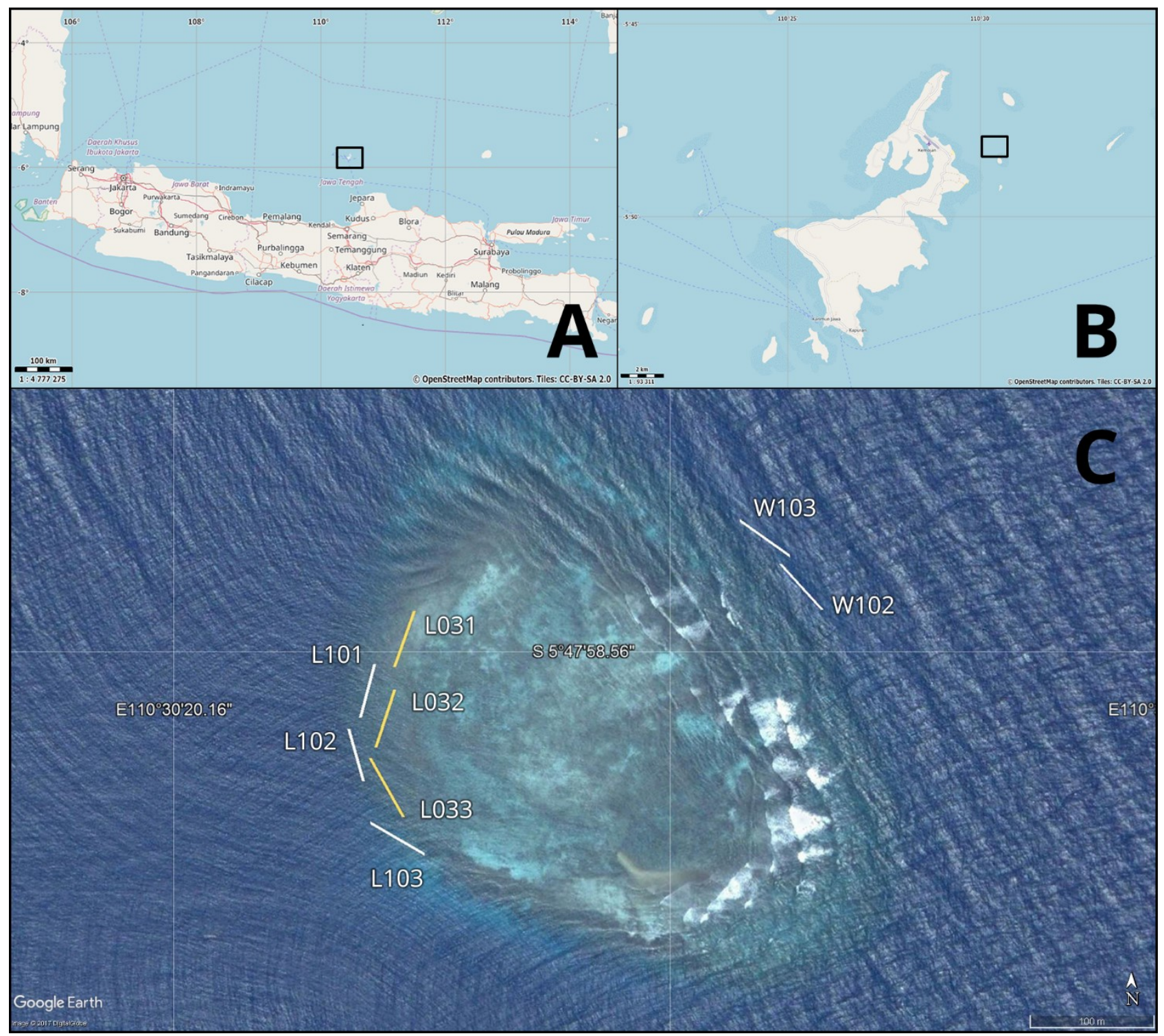

Figure 1. The map of Java Island showing Karimunjawa Islands (A). The map of Karimunjawa Islands showing the area of Tengah patch-reef (B). The Google Earth imagery of Tengah patch-reef in 2017 showing transect position at $3 \mathrm{~m}$ depth (yellow transects of L031, L032, L033) and 10-meter depth (white transects of L101, L102, L103, W102, W103)

\section{METHODS}

The fieldwork was conducted in August 2011 in the Tengah patch-reef of Karimunjawa Islands. We applied Line Intercept Transect (LIT) to estimate the coral lifeform diversity and the live coral cover of the reef (English et al., 1997). Stratified random sampling was implemented to cover eight 50-meter length transects with a 10-meter interval in the study site. A series of three transects were set parallel to the reef rim each at 3 and $10 \mathrm{~m}$ depths on the leeward side, while on the windward side, only two transects were placed at $10 \mathrm{~m}$ depth due to less coral, and no coral was found at 3-meter depth (Table 1). The bleaching coral was marked on the recorded lifeforms along the transect.

Table 1. Transect code and placement

\begin{tabular}{lll}
\hline Depth & Leeward & Winward \\
\hline 3 meter & L031, L032, L032 & - \\
10 meter & L101, L102, L103 & W102, W103 \\
\hline
\end{tabular}

Coral diversity was analyzed based on coral lifeform category and presented as lifeforms composition. The percentage of live corals cover was measured using formulas of English et al. (1994), to describe coral reef health condition. The criteria for coral health determination was referred to Gomez \& Yap (1988) and the Regulation of The State Minister of Environment No. 4/2001. The percent cover of live coral was divided into four criteria, $0-24.9 \%$, $25-49.9 \%, 50-74.9 \%$, and $75-100 \%$ representing poor, moderate, good, and excellent coral reef health conditions respectively. The bleaching data was presented as a ratio of a bleaching coral per lifeform to the total bleaching coral (\%). The lifeform with the highest bleaching occurrence was assumed as the most vulnerable coral to face bleaching due to environmental stress.

\section{RESULTS AND DISCUSSIONS}

There were 13 coral lifeforms observed in the Tengah patch-reef of Karimunjawa Islands (Table 2), consisting of Acropora and non-Acropora lifeforms. The Acropora lifeform covered Acropora branching, Acropora encrusting, Acropora submassive, Acropora digitate, and Acropora tabulate. The non-Acropora 
lifeform comprised of branching coral, encrusting coral, foliose coral, massive coral, mushroom coral, Heliopora, Millepora, and submissive coral. The number of coral lifeforms found in the Tengah patchreef was considered high by the occurrence of all coral lifeform categories. This finding was different compared to the works of Guntur et al. (2016) and Rosi et al. (2016) conducted in Mandangin Island of Sampang Regency which only found 2-5 lifeforms. Similar studies done by Ginoga et al. (2016) reported six lifeforms in East Ratatotok Village of South Minahasa Regency.

In this study, the lowest lifeform diversity was recorded on transect $\mathrm{L} 032$ with six lifeforms at $3 \mathrm{~m}$ depth, i.e., Acropora branching, Acropora digitate, Acropora tabulate, branching coral, encrusting coral, foliose coral, and massive coral. The highest lifeforms diversity was also found at $3 \mathrm{~m}$ depth with nine lifeforms on transect L031 and L033. The L031 transect included Acropora branching, Acropora encrusting, Acropora digitate, Acropora tabulate, branching coral, encrusting coral, foliose coral, massive coral, and mushroom coral. The L033 transects consisted of Acropora branching, Acropora submassive, Acropora digitate, Acropora tabulate, branching coral, encrusting coral, foliose coral, massive coral, and mushroom coral.

This study found Acropora branching and foliose coral dominated the coral diversity at $3 \mathrm{~m}$ depth. The abundance of those two lifeforms was due to the high sediments carried by the current. Suharsono (1996) suggested that sediments in the water column determine the coral lifeforms in the affected area. He reported Acropora branching and foliose coral tends to grow or better adapted in the high sediment waters, whereas Acropora tabulate tends to inhabit in clear water or with low sedimentation.

The highest lifeform diversity in this study was shown by $10 \mathrm{~m}$ depth on the W102 transect with 11 lifeforms including Acropora branching, Acropora submassive, Acropora digitate, Acropora tabulate, branching coral, encrusting coral, foliose coral, massive coral, mushroom coral, submissive coral, and Millepora. The lowest coral diversity at this depth was observed on W101 transect with seven lifeforms composed of Acropora branching, Acropora tabulate, branching coral, encrusting coral, foliose coral, massive coral, and mushroom coral.

The highest coral diversity was found on transect W102 because it is situated on the windward side. This side facing directly to wind that brings constant and strong water flows causes the coral to grows optimally. According to Andaris (2015), water circulation is essential for coral growth due to its oxygen and food supply, as well as flushing of the coral surfaces thus clearing sediments to keep the photosynthetic endosymbiont obtains sufficient light.

The prevailing surface current in Karimunjawa waters is tidal current that moves from the east to southwest with the surface current speed recorded varies from 0.003 to $0.008 \mathrm{~m} . \mathrm{sec}^{-1}$ (Yulvia et al., 2012), 0.055 to $0.350 \mathrm{~m} . s e c^{-1}$ (Yusuf et al., 2012), and 0.05 to

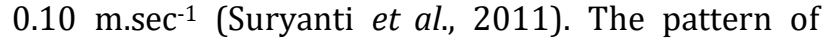
current in the Karimunjawa Islands is mostly caused by the climate oscillation in Indonesian waters (Sya'rani \& Suryanto, 2006), which also depends on the seasons, areas, and types of currents (Tomascik et al., 1997).

Table 2. The diversity of lifeforms and percent cover of coral in the Tengah patch-reef, Karimunjawa Islands

\begin{tabular}{|c|c|c|c|c|c|c|c|c|}
\hline \multirow{2}{*}{ Lifeforms } & \multicolumn{8}{|c|}{ Transects (\%) } \\
\hline & L031 & L032 & L033 & L101 & L102 & L103 & W101 & W102 \\
\hline \multicolumn{9}{|l|}{ Acropora } \\
\hline Acropora branching & 12,36 & 20,00 & 10,75 & 11,89 & 0,80 & 10,90 & 15,45 & 23,09 \\
\hline Acropora encrusting & 1,76 & - & - & - & 4,40 & - & - & - \\
\hline Acropora submassive & - & - & 0,56 & - & 7,00 & 5,10 & - & 3,70 \\
\hline Acropora digitate & 2,83 & - & 1,99 & 0,72 & - & - & - & 3,23 \\
\hline Acropora tabulate & 10,40 & 16,52 & 9,38 & 2,55 & - & - & 3,99 & 5,54 \\
\hline Total lifeform & 4,00 & 2,00 & 4,00 & 3,00 & 3,00 & 2,00 & 2,00 & 4,00 \\
\hline Total coral cover & 27,35 & 36,52 & 22,68 & 15,16 & 12,20 & 16,00 & 19,44 & 35,56 \\
\hline \multicolumn{9}{|l|}{ Non-Acropora } \\
\hline Branching & 6,22 & 19,18 & 14,33 & 6,71 & - & 7,80 & 8,86 & 6,93 \\
\hline Encrusting & 7,07 & 2,21 & 8,58 & 9,44 & 0,20 & 4,10 & 6,32 & 3,23 \\
\hline Foliose & 12,52 & 8,30 & 22,37 & 15,24 & 2,40 & 9,20 & 6,68 & 9,93 \\
\hline Massive & 12,58 & 11,17 & 7,09 & 17,86 & 2,60 & 5,90 & 15,56 & 4,39 \\
\hline Mushroom & 2,46 & - & 0,52 & 0,59 & 0,60 & 0,70 & 0,42 & 1,85 \\
\hline Heliopora & - & - & - & - & - & 0,10 & - & - \\
\hline Millepora & - & - & - & - & 2,40 & 0,20 & - & 3,69 \\
\hline Submassive & - & - & - & - & - & - & - & 4,85 \\
\hline Total lifeform & 5,00 & 4,00 & 5,00 & 5,00 & 5,00 & 7,00 & 5,00 & 7,00 \\
\hline Total coral cover & 40,85 & 40,86 & 52,89 & 49,84 & 8,20 & 28,00 & 37,84 & 34,87 \\
\hline \multicolumn{9}{|l|}{ Other } \\
\hline Algae & 0,06 & 0,57 & 0,17 & - & - & - & 4,81 & - \\
\hline Sponge & - & - & - & 1,27 & - & 0,10 & - & - \\
\hline Sand & - & - & - & 19,42 & 58,60 & 16.30 & 1,89 & - \\
\hline Soft Coral & 0,24 & 1,40 & - & 0,70 & 0,20 & 0,40 & 6,03 & 1,62 \\
\hline Rubble & 31,52 & 20,65 & 24,25 & 13,61 & 20,80 & 39,20 & 30,00 & 27,94 \\
\hline Total of lifeform & 9,00 & 6,00 & 9,00 & 8,00 & 8,00 & 9,00 & 7,00 & 11,00 \\
\hline Total of percent cover & 68,20 & 77,38 & 75,57 & 65,00 & 20,40 & 44,00 & 57,27 & 70,43 \\
\hline
\end{tabular}


Table 3. Bleaching based on lifeforms of coral in the Tengah patch-reef, Karimunjawa Islands

\begin{tabular}{|c|c|c|c|c|c|c|c|c|}
\hline \multirow{2}{*}{ Lifeforms } & \multicolumn{8}{|c|}{ Transects (\%) } \\
\hline & L031 & L032 & L033 & L101 & L102 & L103 & W101 & W102 \\
\hline \multicolumn{9}{|l|}{ Acropora } \\
\hline Acropora branching & - & 0.45 & 0.91 & - & - & - & - & - \\
\hline Acropora encrusting & - & - & - & - & - & - & - & - \\
\hline Acropora submassive & - & - & - & - & - & - & & - \\
\hline Acropora digitate & 0.71 & - & - & - & - & - & - & - \\
\hline Acropora tabulate & - & - & & - & - & - & - & \\
\hline \multicolumn{9}{|l|}{ Non-Acropora } \\
\hline Branching & - & - & - & - & - & - & - & - \\
\hline Encrusting & - & - & - & - & - & - & - & - \\
\hline Foliose & - & - & - & - & - & - & - & - \\
\hline Massive & - & - & - & - & - & - & - & - \\
\hline Mushroom & - & - & - & - & - & - & - & - \\
\hline Heliopora & - & - & - & - & - & - & - & - \\
\hline Millepora & - & - & - & - & - & - & - & - \\
\hline Submassive & - & - & - & - & - & - & - & - \\
\hline
\end{tabular}

Acropora branching was found as the most abundant lifeform (23.09\%) on the transect W102 located on the steep windward slope. This finding is in agreement with Suharsono (1996) and Saptarini (2017) reporting that the dominant coral species in a habitat depends on the environmental topology such as Acropora branching that usually lives on the reef slopes. Manuputty $(1990,2008)$ states that the dominant branching coral colony in a reef is due to the quick recovery ability of Acropora spp. They are well adapted to hydrological changes and grow well especially on windward side or on reef flats with a constant strong water flows, a physical water condition that keeps the coral surface clean from any sediment particles. This condition explains why Acropora spp is the coral group with the most extensive cover and distribution on the windward side.

Budiyanto (2000) showed that coral bleaching and mortality occurred in Karimunjawa Islands were mainly species from the genus Acropora. According to Rani (2001), reef-building corals have different sensitivity to adapt the temperature rise. For example, massive corals are more adaptable to temperature rise than Acropora. Therefore massive corals tend to have a better recovery. Baird (2008) corroborates that Acropora spp are more susceptible to bleaching with the various impact due to the different sensitivity of Symbiodinium and coral species in response to the temperature rise. According to Hughes et al. (2003), extensive geographic variation in bleaching threshold in a species of coral provides indirect evidence that the evolution of temperature tolerance of corals is in progress.

In this study bleaching event only occurred at $3 \mathrm{~m}$ depth, while at $10 \mathrm{~m}$ depth no bleaching coral was located. This because the extreme temperature rise primarily occurs in the shallow waters. According to Coles \& Jokiel (1977) and Rani (2001), the increase of coral mortality during the bleaching event is determined by the increment of temperature and the exposure to the water condition above the average maximum summer temperatures. A small increase in water temperature from the threshold $\left(2-3^{\circ} \mathrm{C}\right) \mathrm{might}$ result in extensive deaths in coral communities. The water temperature recorded in the Tengah patch-reef at the time of observation was $30^{\circ} \mathrm{C}$, within the mean water temperature of Karimunjawa Islands recorded by Yulvia et al. (2012) of $30.0-30.5^{\circ} \mathrm{C}$. A normal and tolerable temperature by the coral, but the daily tidal condition strongly influences the maximum sea surface temperature. Also, the lower low water level of tide can also expose corals to direct sunlight. Some corals can adapt and survive the stress of temperature rise and will have better opportunity to withstand in the next bleaching events.

The water salinity was recorded $32 \%$ at the time of the study, which is a normal condition for coral growth and within the average water salinity in Karimunjawa Islands (Yulvia et al., 2012). According to Dahuri (2003), euryhaline hermatypic corals cannot survive outside the salinity range of 32-36 \%o. However, Supriharyono (2000) suggested that every coral species has different salinity tolerance threshold.

The live coral cover showed that the Tengah patchreef at the $3 \mathrm{~m}$ depth has more cover (73.71\%) compared to the $10 \mathrm{~m}$ depth (50.42\%) (Table 2). At 3 $\mathrm{m}$ depth, the cover was found only in the leeward side from 68.20 to $77.38 \%$, demonstrating a good coral reef condition according to Gomez \& Yap criteria (1988) and the Regulation of The State Minister of Environment No. 4/2001. This good coral condition is caused by optimum sunlight intensity used by zooxanthellae inside the coral tissue for photosynthesis (Hadie, 2008; Mukholladun, 2016). This record supports Giyanto \& Budiyanto (2008) finding that the stony coral has a maximum growth rate at $3 \mathrm{~m}$ depth in the Gulf of Lampung.

The average live coral cover at $10 \mathrm{~m}$ depth was $50.42 \%$, which falls under a good criterion coral reef health. However, the lowest live coral cover was also found on transect L102 and L103 with a value of $20.44 \%$ and $44.0 \%$, a poor and moderate coral reef health, respectively. Both transects were on the leeward side characterized by sand dominating substrates. The presence of sand and mud are not a favorable substrate for planula according to Thamrin 
(2006). The highest live coral cover in this study was $70.43 \%$ on W102 transect on the windward side. The strong current flows on the windward side help cleaning up the corals from sediment (Thamrin, 2006).

\section{CONCLUSION}

The diversity of corals on the Tengah patch-reef of Karimunjawa Islands was high indicated by the occurrence of all coral lifeforms. The highest coral diversity was observed at $10 \mathrm{~m}$ depth with 13 lifeforms, and the lowest was at $3 \mathrm{~m}$ depth with ten lifeforms. The live coral cover reached $73.71 \%$ at $3 \mathrm{~m}$ depth and $50.42 \%$ at $10 \mathrm{~m}$ depth, both indicating a good coral reef health. The bleaching event was detected on Acropora branching, and Acropora digitate less than $1 \%$, suggesting the high sensitivity and vulnerability of Acropora lifeform to exposed environmental stresses.

\section{REFERE NCES}

Andaris AR, Suryanto A, Muskananfola MR. 2015. Hubungan Faktor Fisik-Kimia Perairan Terhadap Tutupan Terumbu Karang Di Pulau Karimunjawa. Manag. Aquat. Resour. J. 4:29-36. [accessed 2017 Nov 14]. http://ejournal3.undip.ac.id/ index.php/maquares/article/view/9206.

Baird AH, Bhagooli R, Ralph PJ, Takahashi S. 2009. Coral bleaching: the role of the host. Trends Ecol. Evol. 24:16-20. doi:10.1016/j.tree.2008.09.005. [accessed 2017 Oct 29]. http://www.ncbi.nlm.nih.gov/pubmed/19022522.

Biondi I, Munasik M, Koesoemadji K. 2014. Kondisi Terumbu Karang Pada Lokasi Wisata Snorkeling Di Kepulauan Karimunjawa, Jawa Tengah. Diponegoro J. Mar. Res. 3:194-201. [accessed 2017 Oct 29]. https://www.neliti.com/publications/ 89670/kondisi-terumbu-karang-pada-lokasi-wisatasnorkeling-di-kepulauan-karimunjawa-ja.

Burke L, Selig E, Spalding M, Lestari YA. 2002. Reefs at Risk in Southeast Asia. World Resources Institute.

Coles SL, Jokiel PL. 1977. Effect of temperature of photosynthesis and respiration in hermatypic corals. Marine Biology. 43:209216.

Dahuri R. 2003. Keanekaragaman hayati laut: aset pembangunan berkelanjutan Indonesia. Jakarta: Gramedia Pustaka Utama.

Edinger EN, Jompa J, Limmon GV, Widjatmoko W, Risk MJ. 1998. Reef Degradation and Coral Biodiversity in Indonesia: Effects of Land-based Pollution, Destructive Fishing Practices and Changes Over Time. Marine Pollution Bulletin. 36(8):617-630

Ekayogiharso E, Munasik M, Prasetyawan IB. 2014. Studi Arus Laut Dan Sedimen Dasar Dalam Hubungannya Dengan Kondisi Terumbu Karang Di Perairan Pulau Parang Kepulauan Karimunjawa Jepara Jawa Tengah. J. Oseanografi 3:181-190. [accessed 2017 Oct 29]. https://www.neliti.com/publications/ 117138/studi-arus-laut-dan-sedimen-dasar-dalamhubungannya-dengan-kondisi-terumbu-karan.

English SA (Susan A, Baker VJ, Wilkinson CR. 1997. Survey manual for tropical marine resources. Townsville: Australian Institute of Marine Science. [accessed 2017 Oct 29]. http://www. worldcat.org/title/survey-manual-for-tropical-marineresources/oclc/647693380.

Fitt W, Brown B, Warner M, Dunne R. 2001. Coral bleaching: interpretation of thermal tolerance limits and thermal thresholds in tropical corals. Coral Reefs 20:51-65. doi:10.1007/s003380100146. [accessed 2017 Oct 29]. http://link.springer.com/10.1007/s003380100146.

Gattuso J-P, Jaubert J. 1990. Effect of light on oxygen and carbon dioxide fluxes and on metabolic quotients measured in situ in a zooxanthellate coral. Limnol. Oceanogr. 35:1796-1804. doi:10.4319/lo.1990.35.8.1796. [accessed 2017 Oct 29]. http://doi.wiley.com/10.4319/lo.1990.35.8.1796.
Ginoga DA, Katili DY, Papu A. 2016. Kondisi Tutupan Karang di Desa Ratatotok Timur Kabupaten Minahasa Tenggara. Jurnal Mipa Unsrat Online. 5(1):14-19

Giyanto, Budiyanto A. 2008. Struktur komunitas karang batu dan kondisi terumbu karang di perairan Teluk Lampung. Oseanologi dan Limnologi di Indonesia. 34(2):199-221.

Gomez ED, Yap HT. 1988. Monitoring Reef Condition. In RA Kenchington, BET Hudson. Coral Reef Management Hand Book. UNESCO Regional Office for Science and Technology for South East Asia. Jakarta. p. 187-195

Gordon MS, Kelly HM. 1962. Primary Productivity of a Hawaiian Coral Reef: A Critique of Flow Respirometry in Turbulent Waters. Ecol. Soc. Am. 43:473-480. doi:10.1016/00117471(63)90572-2. [accessed 2017 Oct 29]. http://www. jstor.org/stable/1933375?seq=1\#page_scan_tab_contents.

Guan Y, Hohn S, Merico A. 2015. Suitable environmental ranges for potential coral reef habitats in the tropical ocean. PLoS One 10:e0128831. doi:10.1371/journal.pone.0128831. [accessed 2017 Oct 29]. http://www.ncbi.nlm.nih.gov/pubmed/ 26030287

Guest JR, Low J, Tun K, et al. 2016. Coral community response to bleaching on a highly disturbed reef. Scientific Reports. 6:20717. doi:10.1038/srep20717.

Guntur, Arifin S, Luthfi OM. 2016. Komposisi Penyusun Terumbu Karang Tepi (Fringing Reef) Di Pulau Mandangin Kabupaten Sampang, Madura. Jurnal Saintek Perikanan. 11(2):94-98

Habibi A, Setiasih N, Sartin J. 2008. A decade of reef check monitoring: Indonesian coral reefs, condition and trends. The Indonesian Reef Check Network. 32.

Hadie W. 2008. Konservasi terumbu karang: melalui budidaya karang hias sebagai komoditas ekspor. Jurnal Ilmiah Faktor Exacta. 1(2):56-63.

Helfinalis. 1998. Pengaruh sedimen dasar, suspensi, suhu, dan salinitas terhadap kehidupan karang di perairan sebelah barat pulau Karimunjawa. Jakarta: Puslitbang Oceanografi LIPI.

Hoogenboom MO, Campbell DA, Beraud E, Dezeeuw K, FerrierPagès C. 2012. Effects of light, food availability and temperature stress on the function of photosystem II and photosystem I of coral symbionts. PLoS One 7:e30167. doi:10.1371/ journal.pone.0030167. [accessed 2017 Oct 29]. http://www. ncbi.nlm.nih.gov/pubmed/22253915.

Hughes TP, Baird AH, Bellwood DR, Card M, Connolly SR, Folke C, Grosberg R, Hoegh-Guldberg O, Jackson JB, Kleypas J, Lough JM. 2003. Climate change, human impacts, and the resilience of coral reefs. Science. 1(5635):929-33.

Januardi R, Hartoko A, Purnomo PW. 2016. Analisis Habitat dan Perubahan Luasan Terumbu Karang di Pulau Menjangan Besar, Kepulauan Karimunjawa Menggunakan Citra Satelit. J. Manag. Aquat. Resour. 5:302-310. [accessed 2017 Oct 29]. https://www.neliti.com/publications/190925/analisis-habitatdan-perubahan-luasan-terumbu-karang-di-pulau-menjanganbesar-ke.

Kohn AJ, Helfrich P. 1957. Primary Organic Productivity of a Hawaiian Coral Reef. Limnol. Oceanogr. 2:241-251. doi:10.1002/lno.1957.2.3.0241. [accessed 2017 Oct 29]. http://doi.wiley.com/10.1002/lno.1957.2.3.0241.

Larosa ES, Purnomo PW, Subiyanto -. 2015. Perbandingan Nilai Hue pada Beberapa Jenis Karang Berdasarkan Status Penutupannya di Pulau Karimunjawa. J. Manag. Aquat. Resour. 4:96-104. [accessed 2017 Oct 29]. https://www.neliti.com/publications/ 191373/perbandingan-nilai-hue-pada-beberapa-jenis-karangberdasarkan-status-penutupanny.

Lewis JB. 1977. Processes Of Organic Production On Coral Reefs. Biol. Rev. 52:305-347. doi:10.1111/j.1469-185X.1977. tb00836.x. [accessed 2017 Oct 29]. http://doi.wiley.com/ 10.1111/j.1469-185X.1977.tb00836.x.

Mukholladun W, Insafitri, Effendy M. 2016. Laju Pertumbuhan Karang Goniastrea sp Pada Kedalaman Yang Berbeda Di Pulau Mandangin Kabupaten Sampang. Prosiding Seminar Nasional Kelautan 2016 Universitas Trunojoyo Madura, 27 Juli 2016. p. $70-74$

Manuputty AEW. 1990. Sebaran, keanekaragaman dan komposisi karang batu di perairan Kabil. Jakarta: Pusat Penelitian dan Pengembangan Oseanografi, LIPI. pp.15-23 
Manuputty AEW. 2008. Profil terumbu karang dengan teknik "rapid reef resource inventory" di pulau-pulau Karimunjawa, Jawa Tengah. Oseanologi dan Limnologi di Indonesia. 34:25-46.

Manuputty AEW, Budiyanto A. 2000. Sebaran spasial karang mati di perairan Karimunjawa, Jawa Tengah. Pros. Lok. Pengelolaan \& Iptek Terumbu Karang Indonesia. 1999 November 22-23; Jakarta. LIPI dan COREMAP;pp.177-187.

Muscatine L, Cernichiari E. 1969. Assimilation Of Photosynthetic Products Of Zooxanthellae By A Reef Coral. Biol. Bull. 137:506523. doi:10.2307/1540172. [accessed 2017 Oct 29]. http://www.ncbi.nlm.nih.gov/pubmed/28368714.

Nair PVR, Pillai CSG. 1972. Primary productivity of some coral reefs in the Indian seas. [accessed 2017 Oct 29]. http://eprints. cmfri.org.in/6783/.

Ramli I. 2003. Analisis kebijakan pengelolaan sumberdaya terumbu karang di kawasan pulau Geleang dan pulau Burung kepulauan Karimunjawa, Jawa Tengah [tesis]. Universitas DiponegoroSemarang.

Rani C. 2001. ULASAN Pemutihan Karang: Pengaruhnya terhadap Komunitas Terumbu Karang Coral Bleaching: Influences on the Coral Reef Communities. Hayati 8:86-90.

Razak TB. 1998. Struktur Komunitas Karang Berdasarkan Method Transect Garis dan Transect Kuadrat di Pulau Menyawakan, Taman National Karimunjawa, Jawa Tengah. Skripsi Sarjana. Institut Pertanian Bogor. Bogor

Rosi F, Insafitri, Effendy M. 2016. Persentase Tutupan Dan Tipe Life Form Terumbu Karang Di Pulau Mandangin Kabupaten Sampang. Prosiding Seminar Nasional Kelautan 2016 Universitas Trunojoyo Madura, 27 Juli 2016. p.18-25

Saptarini D, Mukhtasor M, Rumengan IFM. 2017. Coral reef lifeform variation around power plant activity: Case study on coasta area of Paiton Power Plant, East Java, Indonesia. Biodiversitas Journal of Biological Diversity. 18(1):116-120

Schoepf V, Stat M, Falter JL, McCulloch MT. 2015. Limits to the thermal tolerance of corals adapted to a highly fluctuating, naturally extreme temperature environment. Sci. Rep.5:17639.

Stoddart DR. 1969. Ecology And Morphology Of Recent Coral Reefs. Biol. Rev. 44:433-498. doi:10.1111/j.1469-185X.1969. b00609.x. [accessed 2017 Oct 29]. http://doi.wiley.com/ 10.1111/j.1469-185X.1969.tb00609.x.

Suharsono. 1996. Jenis - jenis terumbu karang yang umum dijumpai di perairan Indonesia. Jakarta: Pusat Penelitian dan Pengembangan Oseanologi, LIPI.
Sukarno, Hutomo M, Moosa MK, Darsono P. 1981. Terumbu karang di Indonesia:sumber daya, permasalahan dan pengolahannya. Jakarta: Lembaga Oseanografi Nasional, LIPI.

Sulisyati R, Poedjirahajoe E, WF LR, Fandeli C. 2014. Karakteristik Terumbu Karang di Zona Pemanfaatan Wisata Taman Nasional Karimunjawa (Coral Reef Characteristic of Tourism Zone, Karimunjawa National Park). ILMU Kelaut. Indones. J. Mar. Sci. 19:139. doi:10.14710/ik.ijms.19.3.139-148. [accessed 2017 Oct 29]. http://ejournal.undip.ac.id/index.php/ijms/article/view/ 8516

Supriharyono. 2000. Pengelolaan ekosistem terumbu karang. Jakarta: Djambatan.

Suryanti S, Supriharyono S, Indrawan W. 2011. Kondisi Terumbu Karang dengan IndikatorlkanChaetodontidae di Pulau Sambangan Kepulauan Karimun Jawa,Jepara, Jawa Tengah. Bul. Oseanografi Mar. 1. [accessed 2017 Nov 8]. http:// ejournal.undip.ac.id/index.php/buloma/article/view/2988.

Sya'rani L, Suryanto A. 2006. Gambaran umum kepulauan Karimunjawa. Semarang: Unissula Press.

Thamrin. 2006. Karang biologi reproduksi dan ekologi. Pekanbaru: Mina Mandiri pres.

Tomascik T, Mah AJ, Nontji A, Moosa MK. 1997. The ecology of Indonesian seas. Part two. In: The ecology of Indonesia series. Volume III. Singapore: Periplus Edition.

Westmacott S, Teleki K, Wells S, West J. 2000. Pengelolaan terumbu karang yang telah memutih dan rusak kritis. Steffen $\mathrm{JH}$ TERANGI-Yayasan Terumbu Karang Indonesia, alih bahasa.Inggris: IUCN, Gland, Switzerland and Cambridge.

Yulvia D, Yusuf M, Sugianto DN. 2012. Karakteristik Arus, Suhu dan Salinitas di Kepulauan Karimunjawa. Journal of Oceanography. 1(2):186-96.

Yusuf M. 2013. Kondisi terumbu karang dan potensi ikan di perairan taman nasional Karimunjawa, Kabupaten Jepara. Buletin Oseanografi Marina. 2(2):254-260

Yusuf M, Handoyo G, Muslim M, Wulandari SY, Setiyono H. 2012. Karakteristik Pola Arus Dalam Kaitannya dengan Kondisi Kualitas Perairan dan Kelimpahan Fitoplankton di Perairan Kawasan Taman Nasional Laut Karimunjawa. buletin oseanografi marina.10;1(5):63-74. 